\title{
Descriptive epidemiology of primary biliary cirrhosis in the province of Quebec
}

\author{
JeAn-Pierre Villeneuve, MD, Daphna Fenyves, MD, FRCP, Claire Infante-Rivard, MD, PHD
}

\begin{abstract}
J-P VILLENEUVE, D FENYVES, C INFANTE-RIVARD. Descriptive epidemiology of primary biliary cirrhosis in the province of Quebec. Can J Gastroenterol $1991 ; 5(5): 174-178$. Primary biliary cirrhosis (PBC) is a rare disease, but is usually recognized because of the characteristic clinical picture and the diagnostic specificity of antimitochondrial antibody (AMA) determination. Information on the epidemiology of $\mathrm{PBC}$ is limited. The authors have examined the incidence and prevalence of PBC in the province of Quebec, where all short term hospitals are required to classify discharge summary diagnoses according to the International Classification of Diseases. Code 571.6 designates primary or secondary biliary cirrhosis. The authors reviewed the charts of all patients to whom this code was assigned during a six year period (1980-86). Two hundred and twenty-eight subjects satisfied predetermined diagnostic criteria for PBC. The mean annual incidence rate was 3.9 per $10^{6}$ population, and the point prevalence in 1986 was 25.4 per $10^{6}$ population. Ninety-two patients were female, with a mean age at the time of diagnosis of 55.7 years; $89.4 \%$ had positive AMA, and 10.5\% were asymptomatic. As of January 1, 1989, 126 patients were alive, 91 had died, and 11 had undergone liver transplantation. Cumulative five and 10 year survivals from the time of initial diagnosis were $69 \%$ and $49 \%$, respectively. In patients with serum bilirubins greater than $100 \mu \mathrm{mol} / \mathrm{L}(\mathrm{n}=66$ ), cumulative two year survival was $5.5 \%$. These data indicate that the incidence and prevalence of PBC in Quebec are similar to those reported in Ontario and at the lower end of the range of those reported in western Europe. The clinical features and evolution of $\mathrm{PBC}$ are also similar, and serum bilirubin is a major prognostic factor.
\end{abstract}

Key Words: Epidemiology, Incidence, Prevalence, Primary biliary cirrhosis, Prognosis

\section{Épidémiologie descriptive de la cirrhose biliaire primitive au Québec}

RESUME: Bien que rare, la cirrhose biliaire primitive (CBP) est habituellement reconnaissable par ses manifestations cliniques et la spécificité diagnostique des anticorps anti-mitochondrie (AMA). Les données relatives à l'épidémiologie de la CBP sont limitées. Nous avons examiné l'incidence et la prévalence de la CBP au Québec, province où tous les hôpitaux généraux sont tenus de classer les

Division of Hepatology, Hôpital Saint-Luc, Université de Montréal; and School of Occupational Health, McGill University, Montreal, Quebec

Correspondence and reprints: Dr Jean-Pierre Villeneuve, Centre de recherche clinique André-Viallet, 264, René-Lévesque est, Montréal, Québec H2X IP1. Telephone (514) 281-2444, Fax (514) 281-2492

Received for publication May 10, 1991. Accepted September 5, 1991
$\mathrm{P}$ RIMARY BILIARY CIRRHOSIS (PBC) IS characterized by progressive cholestasis and affects chiefly middle aged or elderly women. The disease is rare, but is usually recognized because of the characteristic clinical and histological picture, and the relative diagnostic specificity of antimitochondrial antibody (AMA) determination.

Large series of patients with PBC have been described from the United States and Europe (1-4), whereas smal. ler series were reported from Japan (5). However, population-based studies to estimate incidence or prevalence of the disease are scarce. Most published studies are from western Europe (6-15). Some of these studies have shown regional differences in the prevalence of $\mathrm{PBC}$ and apparent geographical clustering of the disease. Only one study has examined the epidemiology of $\mathrm{PBC}$ in North America (16).

The present study was undertaken to define the incidence and prevalence of $\mathrm{PBC}$ in the province of Quebec (population 6.5 million). Clinical, laboratory and survival data are also presented.

\section{MATERIALS AND METHODS}

Data collection: In the province of Quebec, medical records departments of all short term hospitals are required to classify discharge summary diagnoses according to the International Classification of Diseases (ICD-9) (17) for hospitalized patients (but not for outpatients), and to report them to the 
feuilles médico-administratives conformément à la Classification internationale des maladies et des causes de décès. Le code 571.6 (ICD9) désigne la cirrhose primitive et secondaire. Nous avons étudié les dossiers de tous les patients à qui ce code avait été attribué au cours d'une période de six ans (1980-86). Deux cent vingt-huit sujets ont satisfait au critère de diagnostic préalable de CBP. Le taux d'incidence annuelle moyenne était de $3,9 / 10^{6}$ et la prévalence ponctuelle en 1986 était de $25,4 / 10^{6}$. Quatre-vingt-douze des patients étaient des femmes; l'âge moyen au moment du diagnostic était de 55,7 ans; le test à la recherche d'AMA était positif dans $89,4 \%$ des cas et $10,5 \%$ des sujets étaient asymptomatiques. En date du ler janvier 1989, 126 patients étaient en vie, 91 étaient décédés et 11 avaient subi une transplantation hépatique. Le pourcentage cumulatif de survie à 5 et à 10 ans à compter de la date du diagnostic atteignait 69 et $49 \%$, respectivement. Chez les patients dont le taux de bilirubine sérique était supérieur à $100 \mu \mathrm{mol} / \mathrm{L}(\mathrm{n}=66)$, la survie cumuative à deux ans était de 5,5\%. Ces données indiquent que l'incidence et la prévalence de CBP au Québec sont similaires à celles que l'on rapporte en Ontario et se situent parmi les taux les plus bas relevés en Europe de l'Ouest. Les caractéristiques cliniques et l'évolution de la CBP sont également similaires et les concentrations de bilirubine sérique sont un facteur pronostic majeur.

Ministry of Health and Welfare. In this classification, code 571.6 designates primary or secondary biliary cirrhosis. A number of synonyms are also suggested (chronic nonsuppurative cholangitis, hypertrophic biliary cirrhosis, obstructive biliary cirrhosis, post hepatic biliary cirrhosis, cholangitic or cholangiolitic or pericholangiolitic biliary cirrhosis, and intra-or extrahepatic biliary cirrhosis).

The authors obtained from the Ministry of Health and Welfare of Quebec a list of all short term hospitals which had reported this diagnosis during the six year period between April 1, 1980 and March 31, 1986. Medical records departments were contacted and asked to fill in a questionnaire based on the PBC patients' charts. The information requested included: patient identification (name, address, sex and date of birth); date at which the diagnosis was first established; results of AMA determination, biliary tract visualization and liver biopsy report at diagnosis; past or present history of asthenia, pruritus, upper gastrointestinal bleeding or ascites; and the latest available results of serum bilirubin and alkaline phosphatase determinations.

Diagnostic definitions: For the purpose of the present study, the diagnosis of $\mathrm{PBC}$ was based on one major and three minor criteria. The major criterion was a positive AMA determination. Minor criteria included: liver biopsy compatible with a diagnosis of $\mathrm{PBC}$ ( $\mathrm{PBC}$ was considered likely if a liver biopsy was carried out and if the treating physician made a diagnosis of $\mathrm{PBC}$ on the discharge summary form; slides of liver histology were not reviewed); no evidence of biliary tract obstruction assessed by either cholangiogram, ultrasound examination, computed tomography scan or operative findings; and cholestasis, defined as a serum alkaline phosphatase value greater than twice the upper normal limit.

According to these criteria, diagnosis of PBC was categorized as 'certain' (one major and two or three minor criteria); 'likely' (one major and one minor criterion, or three minor criteria); 'possible' (no major and two minor criteria); and 'unlikely' (no major and one or no minor criterion).

Data analysis: The survival status as of January 1, 1989 and the underlying cause of death were obtained from the population registry of Quebec. Survival curves were estimated according to the Kaplan-Meier method (18). The number of inhabitants of the province of Quebec was obtained from Canadian population census data (19).

\section{RESULTS}

One hundred and four hospitals in Quebec reported a total of 719 cases for which code 571.6 appeared as a reported diagnosis on the discharge summary form. Patient information was obtained for 698 of the 719 eligible
TABLE 1

Diagnoses in 648 patients with code 571.6 hospitalized in the province of Quebec between April 1, 1980 and March 31, 1986

\begin{tabular}{lc}
\hline Diagnosis & $\begin{array}{c}\text { Number of } \\
\text { subjects }\end{array}$ \\
\hline Primary biliary cirrhosis & 287 \\
Secondary biliary cirrhosis & 201 \\
Misclassified & 160 \\
Angiocholitis or & 78 \\
cholangitis (576.1) & \\
Cirrhosis (571.5) & \\
Post necrotic cirrhosis & 25 \\
Cryptogenic cirrhosis & 29 \\
Alcoholic cirrhosis & 19 \\
Miscellaneous & 9 \\
\hline
\end{tabular}

cases (97\% response rate) from 100 hospitals. Fifty cases had been hospitalized in more than one institution; the database therefore comprised 648 patients; their reported diagnoses are shown in Table 1. Primary biliary cirrhosis was listed as a diagnosis in 287 subjects $(44 \%)$, secondary biliary cirrhosis in $201(31 \%)$, and $160(25 \%)$ were misclassified (incorrect allocation of code 571.6).

Among the 287 subjects with reported diagnoses of $\mathrm{PBC}$, four were excluded from analysis because they lived outside Quebec. For the remaining 283 subjects, the criteria defined in the 'Methods' section were used to validate the diagnosis of PBC. Based on these criteria, the diagnosis was considered certain in 187 subjects, likely in 41 , possible in 29, and unlikely in 26. Further analysis was carried out only in patients for whom the diagnosis was considered certain or likely ( 228 subjects) .

Clinical and laboratory data in these 228 subjects are summarized in Table 2. Ninety-two per cent of patients were female and $89.4 \%$ had positive AMA. Mean age at the time of diagnosis was 55.7 years (range 24 to 91 ). Twentyfour patients (10.5\%) were completely asymptomatic. Among symptomatic patients, asthenia was the most common symptom, followed by pruritus, ascites and upper gastrointestinal bleeding. Median serum alkaline phosphatase was $483 \mathrm{U} / \mathrm{L}$, but 11 patients had alkaline phosphatase values within normal limits. Median serum bilirubin 


\section{TABLE 2}

Clinical and laboratory data of 228 subjects with primary biliary cirrhosis

\begin{tabular}{|c|c|}
\hline Parameter & $\%$ \\
\hline Female & 92.1 \\
\hline $\begin{array}{l}\text { Positive antimitochondrial } \\
\text { antibody median titre } \\
(1 / 400)\end{array}$ & 89.4 \\
\hline \multicolumn{2}{|l|}{ Age at time of diagnosis } \\
\hline 20 to 29 years & 3.5 \\
\hline 30 to 39 years & 9.6 \\
\hline 40 to 49 years & 18.4 \\
\hline 50 to 59 years & 30.0 \\
\hline 60 to 69 years & 25.4 \\
\hline 70 to 79 years & 11.4 \\
\hline Older than 80 years & 1.7 \\
\hline Asymptomatic & 10.5 \\
\hline Symptomatic & 89.5 \\
\hline Asthenia & $90^{\circ}$ \\
\hline Pruritus & $70^{\circ}$ \\
\hline Ascites & $43^{*}$ \\
\hline Gastrointestinal bleed & $33^{*}$ \\
\hline \multicolumn{2}{|l|}{ Serum bilirubin ( $\%$ of total cases) } \\
\hline 0 to $34 \mu \mathrm{mol} / \mathrm{L}$ & 51 \\
\hline 35 to $100 \mu \mathrm{mol} / \mathrm{L}$ & 17 \\
\hline 101 to $170 \mu \mathrm{mol} / \mathrm{L}$ & 9 \\
\hline Greater than $170 \mu \mathrm{mol} / \mathrm{L}$ & 20 \\
\hline Not available & 3 \\
\hline
\end{tabular}

was $29 \mu \mathrm{mol} / \mathrm{L}$. The distribution of serum bilirubin values at the last visit during the study period is shown in Table 2.

During the study period (six years), 159 new cases of PBC were diagnosed, for a mean annual incidence rate of 3.9 per $10^{6}$ population.

On March 31, 1986, 166 of the 228 cases of $\mathrm{PBC}$ were alive, and the point prevalence was 25.4 per $10^{6}$ population. The incidence and prevalence of PBC found in the present study and those reported from other countries are shown in Table 3.

Cumulative survival from the time of initial diagnosis is shown in Figure 1. On January 1, 1989, 126 patients were alive, 91 had died, and 11 had undergone liver transplantation (five alive and six dead). Among the 91 who died, 60 deaths were related to liver disease, 28 were unrelated, and the cause of death was unknown in three cases. Cumulative five and 10 year survivals were $69 \%$ and $49 \%$, respectively. To estimate the survival function for PBC, patients who died of causes unrelated to liver disease were excluded, and patients who underwent liver trans-
TABLE 3

Incidence and prevalence of primary biliary cirrhosis

\begin{tabular}{llccc}
\hline Reference & Location & $\begin{array}{c}\text { Incidence/10 } \\
\text { population }\end{array}$ & $\begin{array}{c}\text { Prevalence/ } \\
10^{6}\end{array}$ population & $\begin{array}{c}\text { Number } \\
\text { of cases }\end{array}$ \\
\hline Present study & Canada & 3.9 & 25.4 & 228 \\
Witt-Sullivan et al 1990 (16) & Canada & 3.3 & 22.4 & 206 \\
Triger 1980(7) & England & 5.8 & 54 & 34 \\
Hislop 1980 (8) & England & 10.6 & 40 & 16 \\
Hamlyn et al 1983(9) & England & 10.0 & 56 & 117 \\
Myszor and James 1990 (15) & England & 18.8 & 128.5 & 347 \\
Eriksson et al 1984(6) & Sweden & 13.7 & 92 & 33 \\
Lofgren et al 1985(11) & Sweden & 13.7 & 128 & 21 \\
Danielson et al 1990(14) & Sweden & 13.3 & 151 & 111 \\
Sevenet et al 1986(12) & France & 2.6 & 13 & 31 \\
Cales et al 1988(13) & France & 8.5 & - & 66 \\
Triger et al 1984(10) & Europe & 4.0 & 23 & 569 \\
\hline
\end{tabular}

plantation were considered to have died of liver disease on the day of transplantation; the survival curve was then recalculated. Cumulative five and 10 year survivals were $77 \%$ and $57 \%$, respectively. Among patients who died of liver disease, $37 \%$ were younger than 60 years of age.

The prognostic value of serum bilirubin for survival was also examined (Table 4). The probability of surviving two years was $13.3 \%$ in patients with a serum bilirubin value between 100 and $170 \mu \mathrm{mol} / \mathrm{L}$, and $2.6 \%$ in those with a value greater than $170 \mu \mathrm{mol} / \mathrm{L}$. Thus, among 66 patients with a serum bili-

rubin value greater than $100 \mu \mathrm{mol} / \mathrm{L}$, only $5.5 \%$ were still alive two years later.

\section{DISCUSSION}

To assess the incidence and prev. alence of PBC in Quebec, the authors took advantage of the mandatory reporting of discharge summary diagnoses in Quebec's hospitals, and made the assumption that most physicians would perform a liver biopsy to establish a diagnosis of $\mathrm{PBC}$ and that patients would be hospitalized for this procedure, as liver biopsies were not done on an outpatient basis in this area during

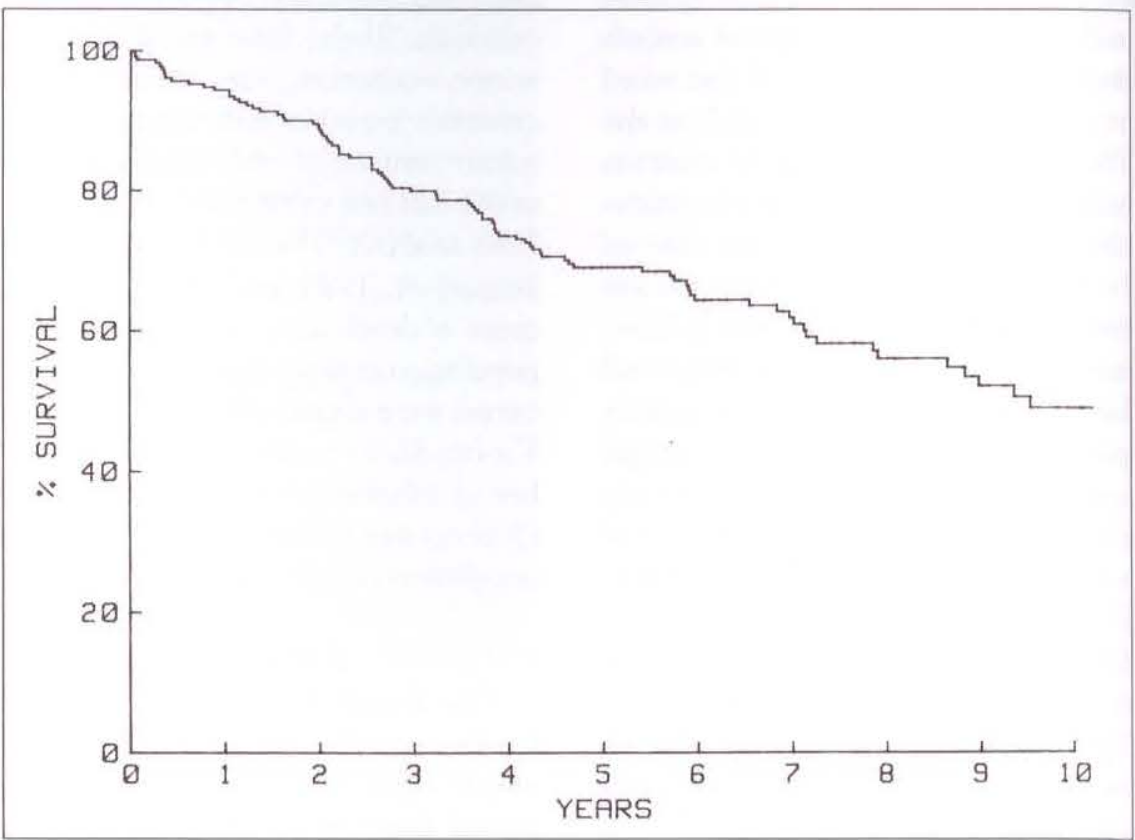

Figure 1) Cumulative survival from time of initial diagnosis in 228 subjects with primary biliary cirrhosis 
TABLE 4

Cumulative survival versus serum bilirubin in 222 patients with primary biliary cirrhosis*

\begin{tabular}{|c|c|c|c|c|}
\hline \multirow{2}{*}{$\begin{array}{l}\text { Serum bilirubin } \\
(\mu \mathrm{mol} / \mathrm{L})\end{array}$} & \multirow{2}{*}{$\begin{array}{c}\text { Number of } \\
\text { patients }\end{array}$} & \multicolumn{3}{|c|}{ Cumulative survival rate (\%) } \\
\hline & & One year & Two years & Three years \\
\hline 0 to 34 & 117 & 95.2 & 90.5 & 86.0 \\
\hline 35 to 100 & 39 & 77.8 & 71.9 & 60.9 \\
\hline 101 to 170 & 21 & 37.5 & 13.3 & 7.1 \\
\hline Greater than 171 & 45 & 4.4 & 2.2 & 0 \\
\hline
\end{tabular}

"Six patients were excluded from analysis because their serum bilirubin values were not available

the study period. There are reasons to believe that the true prevalence and incidence of PBC may be underestimated. First, in 55 cases $(20 \%$ of the database) the diagnosis of $\mathrm{PBC}$ was rejected because of incomplete information, but it is possible that some of these patients did have PBC. Second, patients who were diagnosed as having PBC prior to 1980 , and who did not require hospitalization during the following six years, would not have been detected by the survey method. This would result in a lower estimate of prevalence, but would not affect the estimate of incidence. However, the latter estimate was affected by patients with $\mathrm{BC}$ in whom a diagnosis was made without liver biopsy, since these patients were probably not hospitalized. This may explain the low proportion of subjects with asymptomatic $\mathrm{PBC}$ in this study $(10 \%)$, as physicians may be less inclined to do liver biopsies in such cases. Finally, the existence of cases of PBC that were not recognized or diagnosed would lower the prevalence and incidence.

In most previous studies, underestimation of disease frequency was also likely. Case-finding methods have included voluntary reporting by physicians, examination of hospital admissions, review of pathology reports, review of positive AMA tests, or a combination of the above. Studies relying on voluntary reporting by physicians $(10,12,16)$ are particularly vulnerable to an underestimation bias. Studies which counted cases from hospitalization events $(6,15)$ are potentially less susceptible to such a bias, provided that citizens from the studied areas made exclusive use of the regional or local hospitals from which cases were ascer- tained. This was not a problem in the present study since it included all hospitals in the province. A more subtle problem with this source of data is the change in regional or local hospitalization rates over a period of time: such changes are associated with a number of factors often extraneous to the disease itself - for example, the recruitment of a specialist in an area (15).

It was found that the incidence and prevalence of PBC in Quebec are comparable to those reported by Witt-Sullivan et al (16) in Ontario, and at the lower end of the range of those reported in western Europe (6-15). In Sweden $(6,11,14)$ and northeast England $(9,15)$, the incidence and prevalence of PBC are three to five times higher than those found in Canada (Table 3). It seems unlikely that the methodology used to identify PBC cases could account for such large differences.

The clinical and laboratory features of $\mathrm{PBC}$ in the present study are comparable to those reported in other large studies (1-3). The survival curve of the present group is also almost identical to those of other large series $(3,20,21)$. The shape of the curve, showing a steady decline in survival from the time of initial diagnosis, is of particular interest. If $\mathrm{PBC}$ was diagnosed at a uniform point in time in the natural history of the disease, and if most patients were still alive six to eight years after diagnosis, one would expect the survival curve to be initially flat, and then to decrease fairly sharply after six to eight years. Instead, the steady decline in survival suggests that the natural history of $\mathrm{PBC}$ varies considerably from patient to patient, with some experiencing rapid evolution towards liver failure and others experiencing little progression. The possibility that the diagnosis is made at different times in the course of the disease could also contribute to the shape of the survival curve.

The prognostic value of serum bilirubin in $\mathrm{PBC}$ has been demonstrated by several authors $(1,3,22)$. In the present study, only three of 66 subjects with serum bilirubin values greater than 100 $\mu \mathrm{mol} / \mathrm{L}$ were alive two years later. The study was not designed to assess prognostic factors in PBC, and the authors did not collect the data necessary to validate more complex prognostic models such as the Mayo model (2), Christensen's model (20) or the Yale model (3). Nevertheless, the present data indicate that death was nearly certain among patients with serum bilirubin values greater than $100 \mu \mathrm{mol} / \mathrm{L}$. Thus, serum bilirubin alone at the tested cut-off point will distinguish patients with poor prognoses from those with more favorable ones; PBC patients with serum bilirubin values greater than $100 \mu \mathrm{mol} / \mathrm{L}$ should be considered candidates for immediate liver transplantation. A two year survival rate of $74 \%$ has been reported in PBC patients following liver transplantation, clearly much better than that of untreated patients (23).

In summary, the incidence and prevalence of $\mathrm{PBC}$ in the province of Quebec are similar to those reported in Ontario, and at the lower end of the range of those reported in western Europe. Whether this implies a genuine difference in the epidemiology of PBC or a difference in the degree of awareness of physicians, remains undetermined. The clinical features and evolution of PBC in Quebec appear to be quite similar to those reported from other countries, and serum bilirubin is a major prognostic factor.

ACKNOWLEDGEMENTS: The authors thank Drs Anne Sutton and Gaétanne Routhier, Ms Edith Marcoux, Ginette Raymond, Manon Bourcier, and the medical records department staff for their contritution to this study. Drs Jean-Pierre Villeneuve and Claire Infante-Rivard are 'chercheurs-boursiers' from the Fonds de la recherche en santé du Québec. 


\section{REFERENCES}

1. Christensen E, Crowe J, Doniach D, et al. Clinical pattern and course of disease in primary biliary cirrhosis based on an analysis of 236 patients. Gastroenterology 1980;78:236-46.

2. Dickson ER, Grambsh PM, Fleming TR, Fisher LD, Langworthy A.

Prognosis in primary biliary cirrhosis: Model for decision making. Hepatology 1989;10:1-7.

3. Roll J, Boyer JL, Barry D, Klatskin G. The prognostic importance of clinical and histological features in asymptomatic and symptomatic primary biliary cirrhosis. N Engl J Med 1983;308:1-7.

4. Sherlock S, Scheuer PJ. The presentation and diagnosis of 100 patients with primary biliary cirrhosis. N Engl J Med 1973;189:674-8.

5. Sasaki H, Inoue K, Higuchi K, et al. Primary biliary cirrhosis in Japan: National survey by the subcommittee on autoimmune hepatitis. Gastroenterol Jpn 1985;20:476-85.

6. Eriksson S, Lindgren S. The prevalence and clinical spectrum of primary biliary cirrhosis in a defined population. Scand J Gastroenterol 1984;19:971-6.

7. Triger DR. Primary biliary cirrhosis: An epidemiological study. Br Med J 1980;281:772-5.

8. Hislop WS. Primary biliary cirrhosis:
An epidemiological study. Br Med J 1980;281:1069-70.

9. Hamlyn AN, Macklon AF, James O. Primary biliary cirrhosis: Geographical clustering and symptomatic onset seasonality. Gut 1983;24:940-5.

10. Triger DR, Berg PA, Rodes J. Epidemiology of primary biliary cirrhosis. Liver 1984;4:195-200.

11. Lofgren J, Jarnerot G, Danielsson D, Hemdal I. Incidence and prevalence of primary biliary cirrhosis in a defined population in Sweden. Scand J Gastroenterol 1985;20:647-50.

12. Sevenet F, Capron JP. Les formes asymptomatiques de la cirrhose biliaire primitive observées en 10 ans en Picardie. Presse Med 1986;15:1957-60.

13. Cales P, Cales V, Oksman F, Vinel JP, Pascal JP. Signification des anticorps anti-mitochondrie dans une population de 111 malades issus de la région midi Pyrénées. Presse Med 1988;17:742-5.

14. Danielsson A, Boqvist L, Uddenfeldt P. Epidemiology of primary biliary cirrhosis in a defined rural population in the northern part of Sweden. Hepatology 1990;11:458-64.

15. Myszor M, James OFW. The epidemiology of primary biliary cirrhosis in north-east England: An increasingly common disease? QJ Med 1990;75:377-85.

16. Witt-Sullivan H, Heathcote J, Cauch
K, et al. The demography of primary biliary cirrhosis in Ontario, Canada. Hepatology 1990;12:98-105.

17. International Classification of Diseases, 9th edn. Genève: World Health Organization, 1978.

18. Peto R, Pike MC, Armitage P, et al. Design and analysis of randomized clinical trials requiring prolonged observation. II. Analysis and examples. Br J Cancer 1977;35:1-39.

19. Duchesne L. Statistiques démographiques: La situation démographique au Québec. Bureau de la statistique, Gouvernement du Québec. Les Publications du Québec, 1989.

20. Christensen E, Neuberger J, Crowne J, et al. Beneficial effect of azathioprine and prediction of prognosis in primary biliary cirrhosis. Final results of an international trial. Gastroenterology 1985;89:1084-91.

21. Dickson ER, Fleming TR, Wiener RH, et al. Trial of penicillamine in advanced primary biliary cirrhosis. N Engl J Med 1985;312:1011-5.

22. Shapiro JM, Smith H, Schaffner F. Serum bilirubin: A prognostic factor in primary biliary cirrhosis. Gut 1979;20:137-40.

23. Markus BH, Dickson ER, Grambsch PM, et al. Efficacy of liver transplantation in patients with primary biliary cirrhosis. N Engl J Med 1989;320:1709-13. 


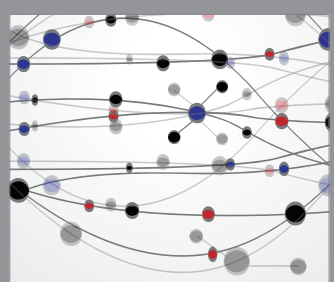

The Scientific World Journal
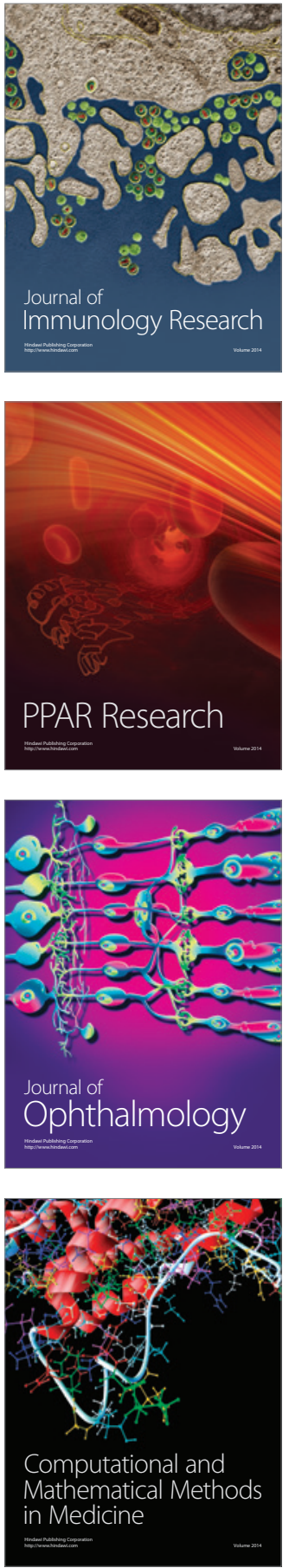

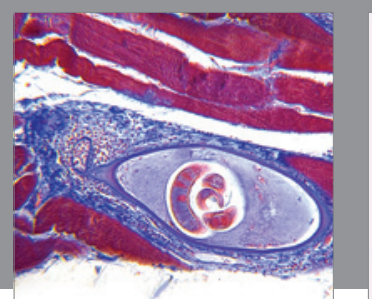

Gastroenterology Research and Practice

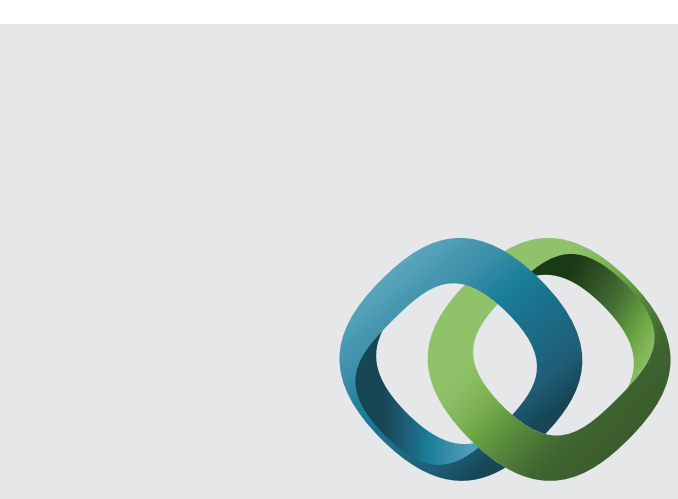

\section{Hindawi}

Submit your manuscripts at

http://www.hindawi.com
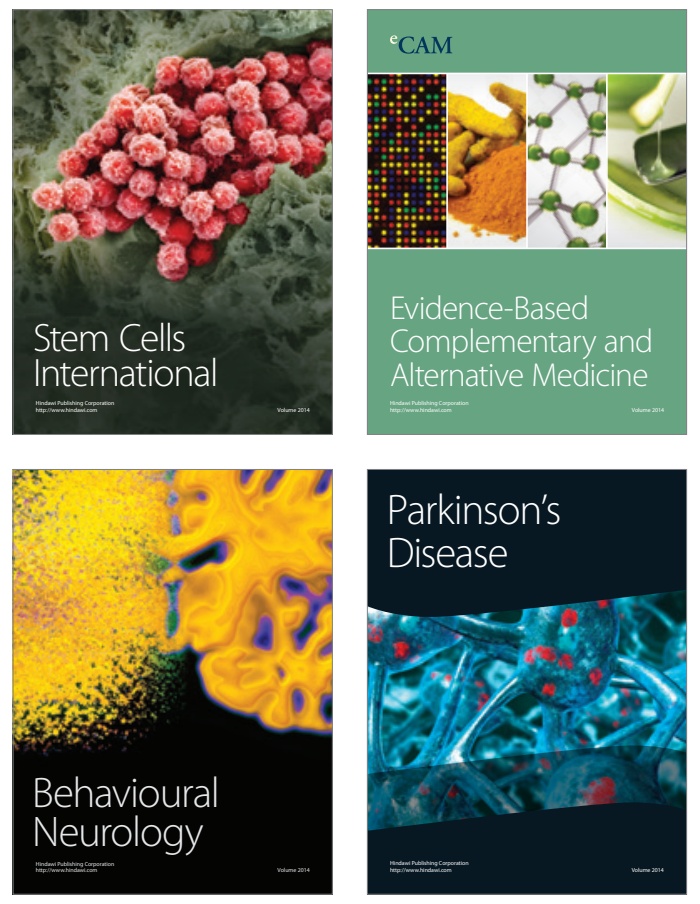
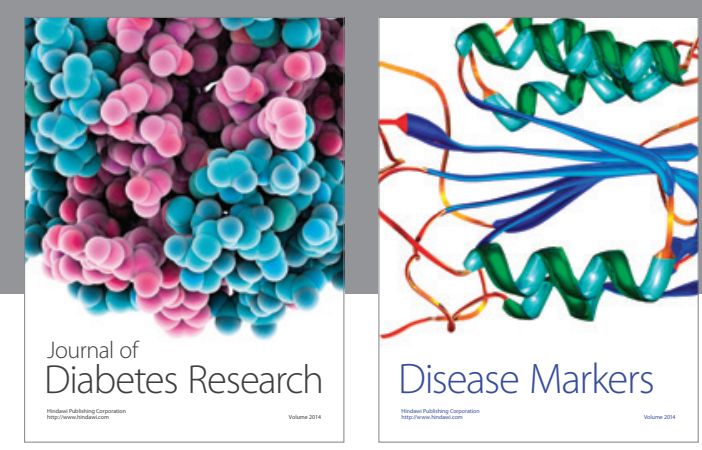

Disease Markers
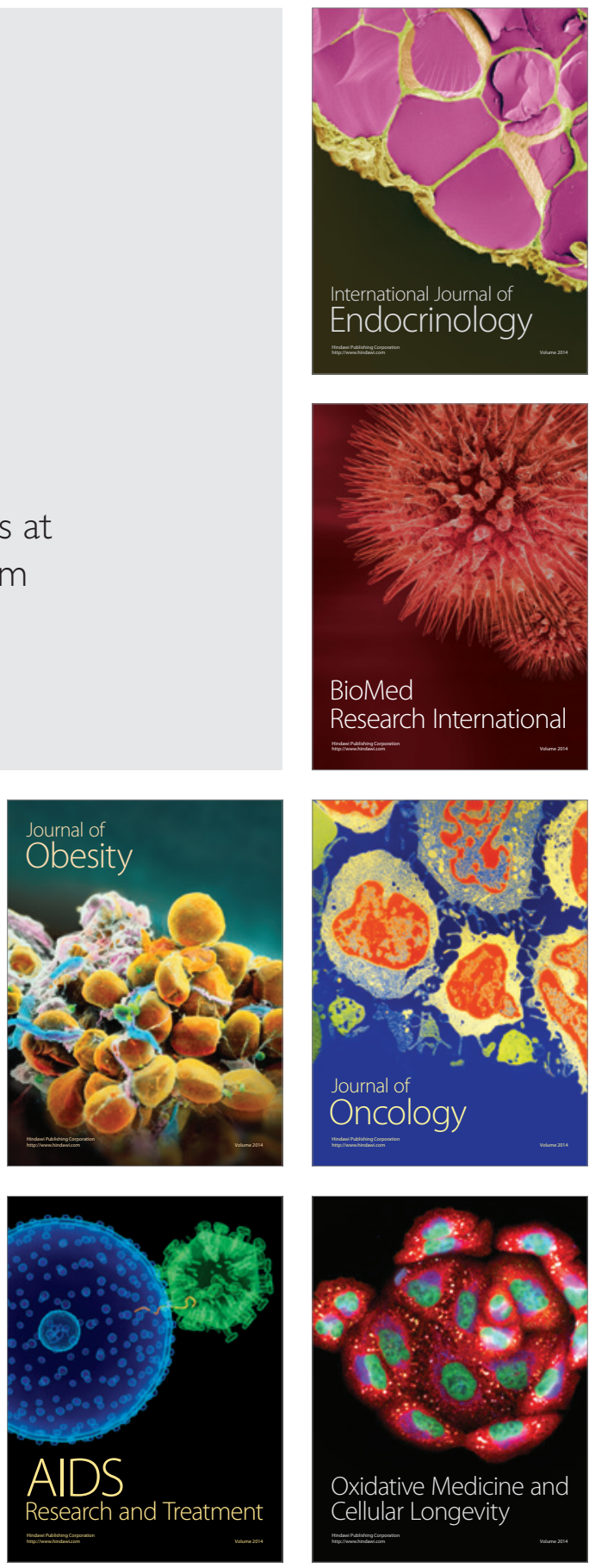